\title{
SPATIAL AND TEMPORAL VARIATIONS IN PHYTOPLANKTON ASSEMBLAGES IN SOUTHAMPTON WATER ESTUARY (SOUTHERN UK) ESTIMATED FROM MICROSCOPIC COUNTS AND HPLC PIGMENT CHEMOTAXONOMY
}

\author{
Elham M. Ali ${ }^{1, *}$; Duncan Purdie ${ }^{2}$ and Arantha Iriarte ${ }^{3}$ \\ ${ }^{1}$ Department of Biological and Geological sciences, Faculty of Education (El- \\ Arish), Suez Canal University, Egypt. \\ ${ }^{2}$ School of Ocean and Earth Sciences, University of Southampton, National \\ Oceanography Centre, Southampton UK. \\ ${ }^{3}$ Department of Plant Biology and Ecology, University of the Basque Country in \\ Bilbao, Spain
}

\begin{abstract}
Phytoplankton biomass and community structure in Southampton Water estuary (on the south coast of the UK) have been investigated. Inter-annual changes in chlorophyll $a$ coupled with changes in total carbon biomass have been analysed in 2004 and 2005 (during the productive period of the estuary). HPLC method has been also used to measure chlorophyll $a$ and other accessory pigments that help, as quantitative biomarkers, to provide information on changing phytoplankton dynamics in such a highly dynamic estuary. Microscopy and chemotaxonomy give a high level of agreement phytoplankton characterization along the estuary; however, some limitations are present in both techniques. HPLC derived chlorophyll $a$ showed a good correlation with the total phytoplankton biomass during the sampling period although it was underestimated in some samples. Fucoxanthin showed a strong correlation with total diatom biomass however high chlorophyll $a$ concentrations during bloom time affected this relationship. Similar finding was obtained for peridinin and Dinoflagellates. Although, Cryptomonas sp. was recorded in some samples, no correlation was detected between its biomass and alloxanthin concentration due to microscopic confusion with small flagellates that were numerically abundant at the same time. Peaks in alloxanthin were, however, coincided with peaks in the biomass of the autotrophic ciliate Mesodinium rubrum. By relating the biomass of specific phytoplankton groups to their corresponding biomarker pigment, the dominance of diatoms (fucoxanthin and chlorophyll $c_{l}+c 2$ ) in spring and dinoflagellates (peridinin) in summer was established. Dinoflagellates as well as ciliates were found to grow better in the intermediate sites along the estuary. Combining the pigments together to give diagnostic indices shows a very similar pattern to that of Chl $a$ as well as carbon biomass microscopically detected. Diagnostic pigment indices (represented as microplankton, picoplankton and nanoplankton) confirmed the previous finding that phytoplankton species succession in Southampton Water started with diatoms and followed by flagellates/ciliates and then dinoflagellates.
\end{abstract}

* Corresponding author: Tel.: +0162239339; Fax: +683350065

(ISSN: 1110-8649)

E-mail address: elhamali05@yahoo.co.uk (Dr. Elham Mohamed Ali) 


\section{Introduction}

In estuarine and coastal waters, phytoplankton is exposed to rapidly changing environmental conditions that may have pronounced effects on their dynamics and community structure. Phytoplankton blooms in Southampton Water, as a macrotidal estuary, are known to be short lived due to 1- rapidly changing conditions of irradiance (i.e. solar irradiance and water column turbidity) and 2- intensity of tidal mixing due to the spring-neap tidal cycle (Holley and Hydes, 2002; Iriarte and Purdie, 2004). Previous analysis of phytoplankton in Southampton Water estuary revealed a sequence of different species that became numerically dominant for short periods (i.e. less than 7 days) during the productive period of the estuary (Ali $\boldsymbol{e t}$ al., 2000 and Ali, 2009) with a mixed diatom community being dominant during spring followed by a large increase in numbers of euglenoid flagellates. Dinoflagellate species grow preferably in summer coincided with high daily irradiance levels. Similar phytoplankton species succession is previously recorded along the estuary. The study of phytoplankton dynamics in such variable environments (like Southampton Water) requires sustained and frequent sampling as well as analysis methodologies that need short time and give reproducible (Schluter et al., 2000). Relevant temporal and spatial scales are also a demand for accurate and reliable determination of the composition of natural phytoplankton communities (Cloern, 1996).

Microscopic analysis is the most reliable technique to enumerate individual species in a mixed natural sample, but it is a time consuming and tedious technique (Millie $\boldsymbol{e t}$ al., 1993) if many samples are analyzed. For accurate identification of phytoplankton species a high level of expertise is also required (Breton et al., 2000). Moreover, cell counting and identification often provide limited information on the small delicate phytoplankton groups that are difficult to identify (Wong and Crawford, 2006) or can not survive sample preservation (Reid, 1983). The high performance liquid chromatography (HPLC) technique is now recognized as a powerful method in oceanography (e.g. Mantoura and Llewellyn, 1983; Barlow et al., 1993; Jeffrey et al., 1997; Schluter et al., 2000 and DiTullio et al., 2003) for analysis of phytoplankton pigments and their degradation products allowing the presence of dominant organisms in mixed assemblages to be evaluated. HPLC also allows the quantification of small phytoplankton cells $(<5 \mu \mathrm{m})$ which may be underestimated in microscopic counts (Rodriguez et al., 2002), and cells with membranes of low visibility, for example, small picoplanktonic green algae (Breton et al., 2000).

At a qualitative level, all previous studies of HPLC pigment analysis in oceans (Claustre et al., 2004; Llewellyn et al., 2008), in estuaries and coastal waters (Llewellyn et al., 2005; Ediger et al., 2006; Ali 2003 and 2009), in Antarctic and sub-arctic environments (Rodriguez et al., 2002; Ras et al., 2008 
and Fujiki et al., 2009) and other marine systems (Llewellyn et al., 2005; Delizo et al., 2007).

In this research we monitor the inter-annual changes in phytoplankton community composition, bloom timing and bloom duration in Southampton Water estuary using microscopic observations, with a view to examine the possibility of using HPLC chemotaxonomy in such a highly changing environment to present a descriptive study of the changes in phytoplankton pigments during the main productive period (Spring/Summer) of the estuary in 2004 and 2005. Our main question is whether these methodologies are comparable and suitable to characterize phytoplankton assemblages in a highly dynamic estuarine system as Southampton Water Estuary.

\section{Materials and Methods}

\section{Study area}

Southampton Water (Southern England) is a partially-mixed estuary, approximately $10 \mathrm{~km}$ long and $2 \mathrm{~km}$ wide being a north-westerly extension of the Solent (Figure 1).

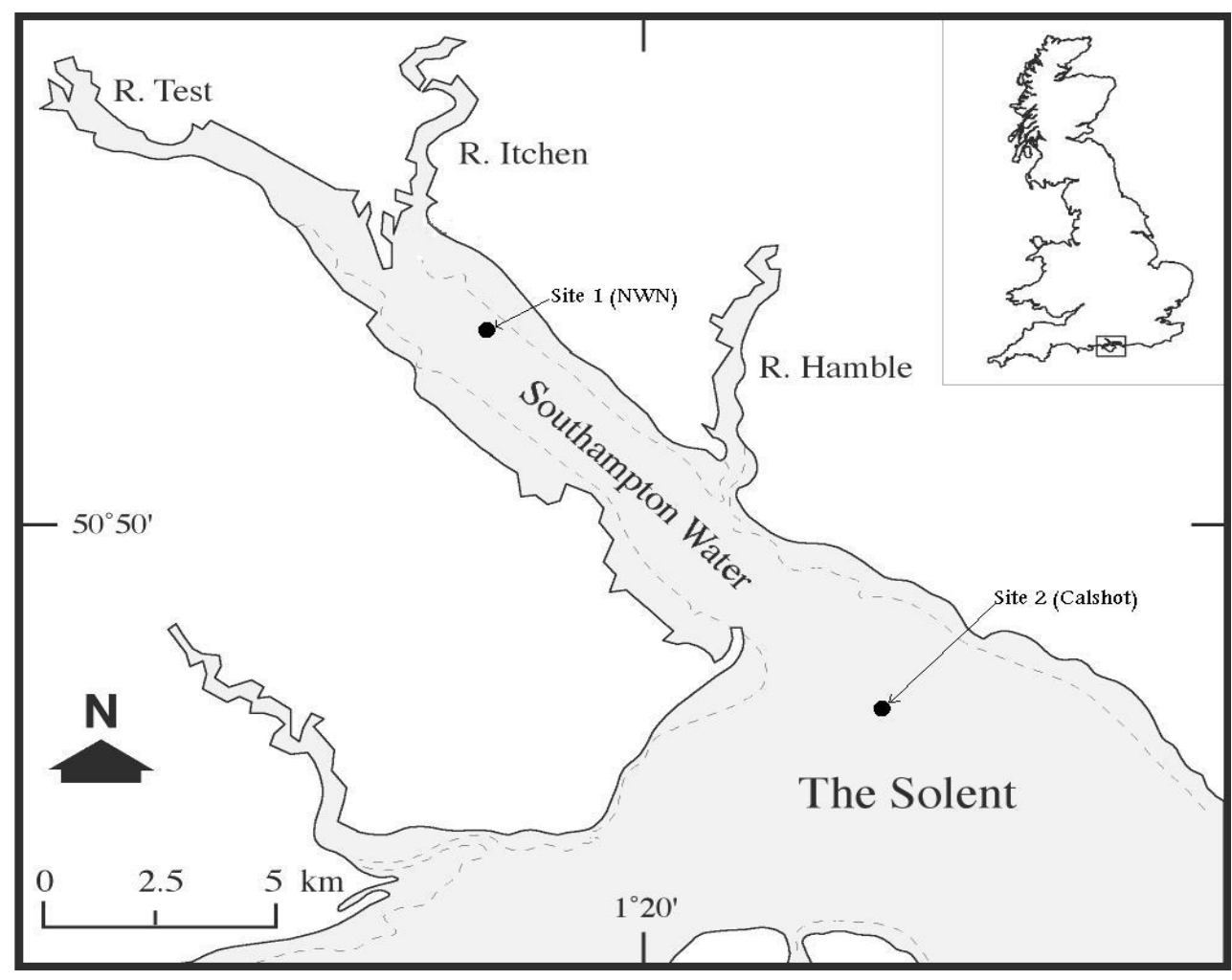

Figure (1): Map of the study area showing the position of the sampling sites (1 and 2) 
The estuarine system is macrotidal (mean tidal range $>4 \mathrm{~m}$ ) and water depth in the dredged deep-water channel is maintained at $10 \mathrm{~m}$ below chart datum to above Southampton Docks. The system receives most fresh water from the rivers Test and Itchen with a mean annual discharge of 8.8 and $3.3 \mathrm{~m}^{3} \mathrm{~s}^{-1}$ respectively. The river Hamble also discharges into the system but makes a minor contribution compared to the other two rivers. Salinity structure along Southampton Water depends on the seasonal cycle of fresh water flow as well as the tidal state (Phillips, 1980). Surface salinity ranges between $\sim 18$ to $>32$. However at the entrance to the system at Calshot, in the open Solent, salinities throughout the water column generally exceeding 34 and the water column remains almost permanently well-mixed (Sylaios and Boxall, 1998).

\section{Sample collection}

Samples were collected from two sampling positions in the estuary (Figure 1), one located in the middle estuary adjacent to North-West Netley buoy (NWN), and the other near Calshot buoy (CA). These sampling sites were chosen to cover different environmental conditions along the main body of the estuary concerning the effect of rive-fresh water inflow. NWN, at the middle of the estuary (Figure 1), represented the medium environment between the fresh-water environment and coastal environment (i.e. medium salinity, medium nutrients). CA, at the mouth of the estuary (Figure 1), is however, represents the coastal high salinity site and less affected by river water (less nutrient). Water samples were collected weekly from March to July in 2004 and from February to September in 2005. Surface water (1m depth) was collected using a 1.5-L Niskin bottle.

\section{Phytoplankton counts}

Aliquots of $100 \mathrm{ml}$ were preserved in acid Lugol's iodine solution (Parsons et al., 1984) and kept in dark bottles until counted. Phytoplankton cells were counted in $10 \mathrm{ml}$ sedimentation chambers using a Flouvert inverted microscope and where possible identified to species level, using Tomas (1997).

\section{Biomass estimation}

Samples for chlorophyll $a$ analysis were filtered $(50 \mathrm{ml})$ through $25-\mathrm{mm}$ diameter GF/F filters and immediately frozen. Chlorophyll $a$ was extracted in 8 $\mathrm{ml}$ of $90 \%$ acetone by sonication followed by centrifugation. Chlorophyll $a$ was measured using a Turner AM10 fluormeter. Chlorophyll $a$ concentration was determined using Parsons' equation (Parsons et al., 1984) and the fluormeter calibrated against a standard Chlorophyll $a$ solution (Sigma Ltd.).

Total phytoplankton biomass (as $\mathrm{mg} \mathrm{C} \mathrm{m}^{-3}$ ) was estimated from microscopic enumeration of cells by estimating cell volume of individually measured cells and converted to carbon using the cell volume/carbon relationship given by Eppley et al. (1970) as described by Holligan $\boldsymbol{e t}$ al. (1984) using a 
standard spreadsheet algorithm provided by Derek Harbour (Kovala and Larrance, 1966). However, carbon values for some species were calculated according to a recent estimate of carbon per cell volume (Menden-Deuer and Lessard, 2000).

\section{HPLC Pigment Measurements}

\section{Method Outline}

Pigments were separated, in this study, by ion-pairing reverse-phase HPLC as described by Mantoura and Llewellyn (1983) and modified by Barlow et al. (1993) using a Perkin Elmer C18 column and a Thermoseparation HPLC system with on line vacuum degasser, a dual solvent pump (P2000), an autosampler (AS3000), a UV detector (UV1000), a fluorometer (FL3000), integrator (SN4000) and integration software PC1000. Pigmet extracts were loaded into the auto-sampler which retained a temperature of $0{ }^{\circ} \mathrm{C}$. A $100 \mu \mathrm{l}$ filtered sample $(500$ $\mu \mathrm{l}$ sample mixed with $500 \mu \mathrm{l} 1 \mathrm{M}$ ammonium acetate) was injected into the column.

\section{Extraction Procedure for HPLC pigment analysis}

One litter water samples were filtered through $47-\mathrm{mm} \mathrm{GF/F}$ filters and frozen immediately. The frozen samples were subsequently extracted in $90 \%$ HPLC-grade acetone by sonication followed by centrifugation. The extracts were filtered through $0.2 \mu \mathrm{m}$ Nylaflo filters and $100 \mu \mathrm{l}$ injected into the HPLC system for pigments analysis. The ion-pairing reverse-phase HPLC technique of Mantoura and Llewellyn (1983) was used as described with modifications by Barlow et al. (1993).

\section{Detection and Identification of Chlorophylls and Accessory Pigments}

Carotenoids pigments were detected by absorbency at $440 \mathrm{~nm}$, however chlorophylls and other degradation products were detected by absorption at 440 $\mathrm{nm}$ as well as by fluorescence with excitation at $410 \mathrm{~nm}$ and emission at wavelengths $>670 \mathrm{~nm}$. Peaks of all pigments were identified by comparing their retention times with authentic standards in acetone obtained from Sigma Chemical Company or DHL, Denmark. An inline photodiode array detector was used in this work for more accurate identification of accessory pigments. This method does not separate chlorophylls $c_{1}$ and $c_{2}$ and so these were reported together as chlorophyll $c_{1}+c_{2}\left(\mathrm{Chl} c_{1}+c_{2}\right)$. Table (1) gives the common accessory pigments used as biomarkers for particular groups of phytoplankton. Phytoplankton community biomass concentration estimated as $\mathrm{C}$ and as $\mathrm{Chl} a$ (or diagnostic pigment) for each date both sites (microscopic and HPLC results, respectively) were compared by simple linear correlations. Level of significance was set as $\mathrm{p}<$ 0.01 for all statistical analysis. 
Table (1): Distribution of major accessory pigments for some phytoplankton taxa as given by Barlow et al., 1993; Jeffrey and Vesk, 1997; Jeffrey et al., 1997.

\begin{tabular}{|l|l|}
\hline \multicolumn{1}{|c|}{ Algal group } & \multicolumn{1}{c|}{ Common pigments } \\
\hline Diatoms & fucoxanthin (Fuc), diadinoxanthin (Diad), diatoxanthin (Diat) \\
\hline Cryptophyceae & alloxanthin (Allo) \\
\hline Blue-green algae & zeaxanthin (Zea), Myxoxanthophyll, echinenone \\
\hline Green algae & violaxanthin (Viol), lutein, zeathanthin (Zea) \\
\hline Dinoflagellates & peridinin (Peri), diadinoxanthin (Diad), fucoxanthin (Fuc) \\
\hline
\end{tabular}

\section{Results}

\section{Chlorophyll a dynamics}

Chlorophyll $a(\mathrm{Chl} a)$ is a universal indicator of phytoplankton and showed wide variations over the sampling years at both sites. The first chlorophyll $a$ (flurometrically measured) bloom $\left(>10 \mathrm{mg} \mathrm{m}^{-3}\right)$ was mostly measured during Spring/summer (Figure 2) with higher chlorophyll $a$ values at mid estuary (NWN) compared with values measured at the mouth of the estuary (Calshot).

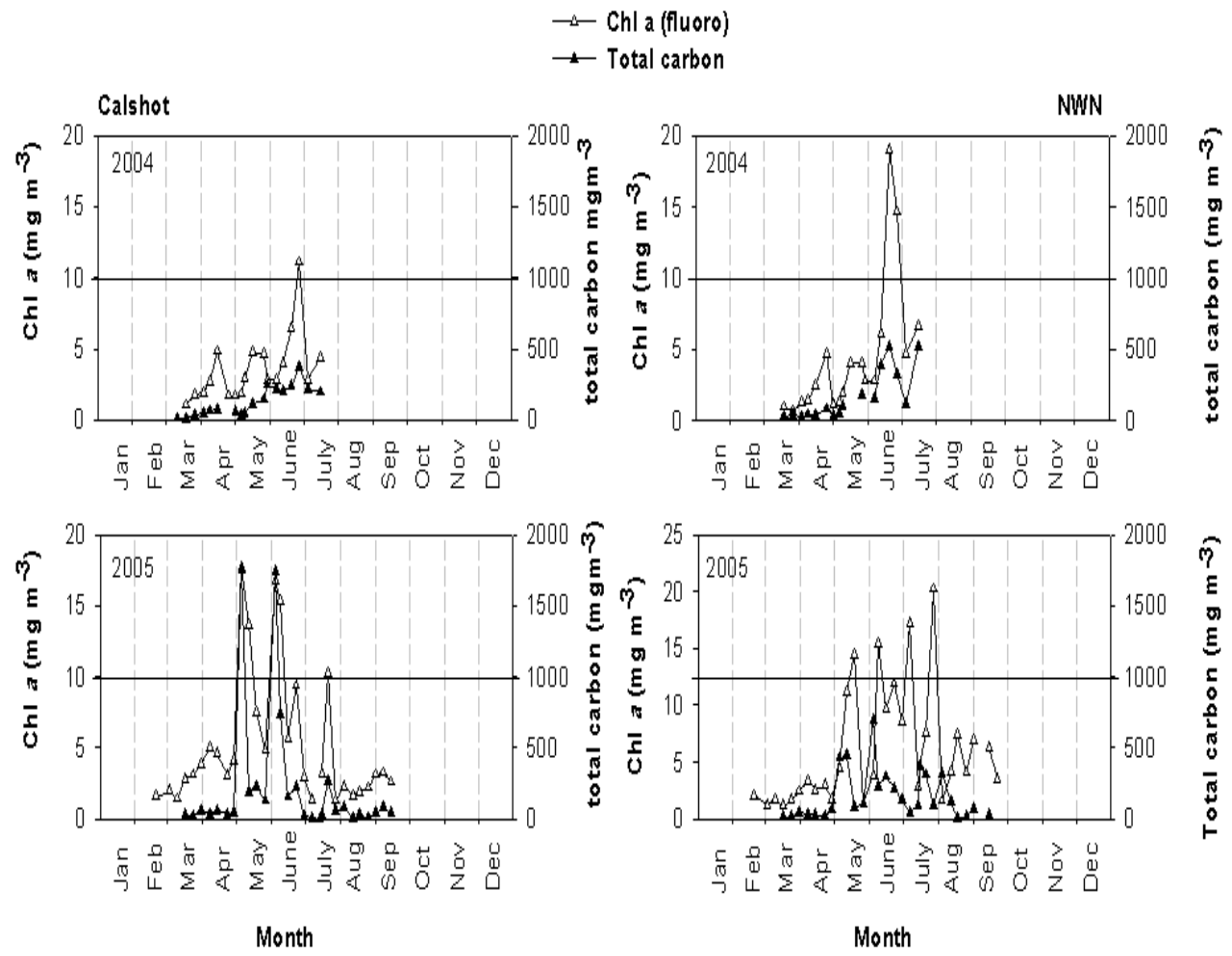

Figure (2): Distribution of fluorometrically estimated Chl $a$ at Calshot (CA) and NW Netley (NWN) during 2004 and 2005 
In 2004, the first and only major chlorophyll $a$ peak recorded at Calshot delayed until end of June $\left(\sim 11 \mathrm{mg} \mathrm{m}^{-3}\right)$ and lasted only for short period (less than a week). This peak was dominated by diatoms (mainly Guinardia delicatula, Rhizosolenia setigera and Cerataulina pelagica). While the delayed major chlorophyll $a$ peak at NWN lasted for a longer period and was dominated by a mixture of both diatoms (mainly Rhizosolenia setigera) and dinoflagellates (Scrippsiella trochoidea). In 2005, many peaks of chlorophyll $a$ were recorded at both sites compared to that in 2004 with 5 and 7 major blooms (>10 $\mathrm{mg} \mathrm{m}^{-3}$ ) measured at Calshot and NWN, respectively (Figure 2).

The early phytoplankton peak events recorded over the sampling period were, in general, dominated by diatoms (with Guinardia delicatula and Thalassiosira rotula the most abundant) at both sites (see Figures 3 and 4); however dinoflagellates (mainly, Scrippsiella trochoidea) dominated the late spring/early summer ones, particularly at NWN.

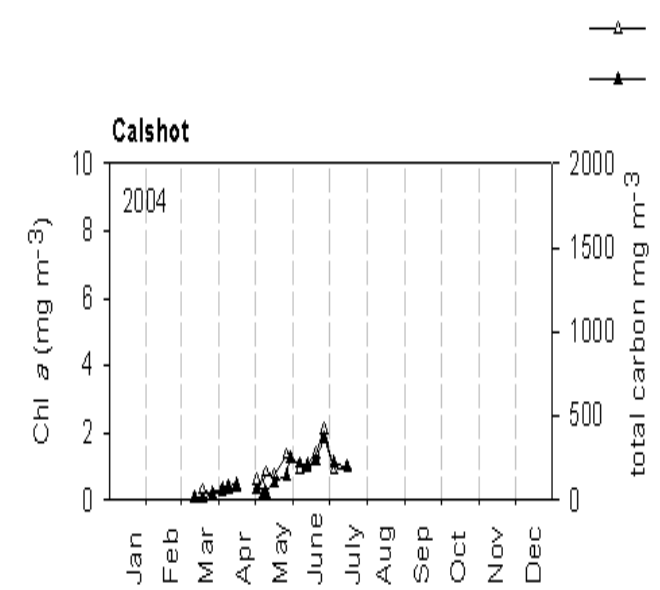

$\rightarrow \mathrm{Chl} a(\mathrm{HPLC})$
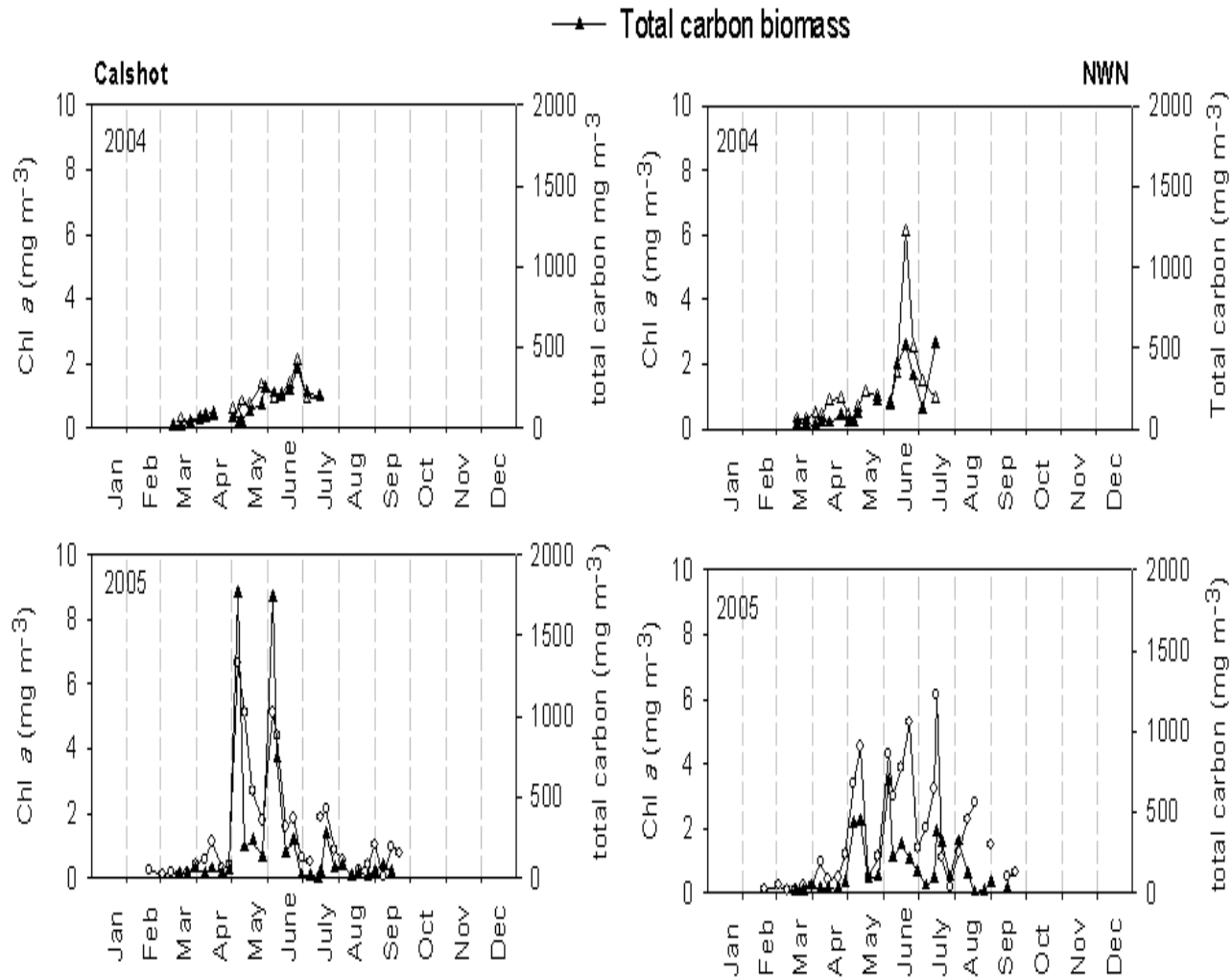

Month

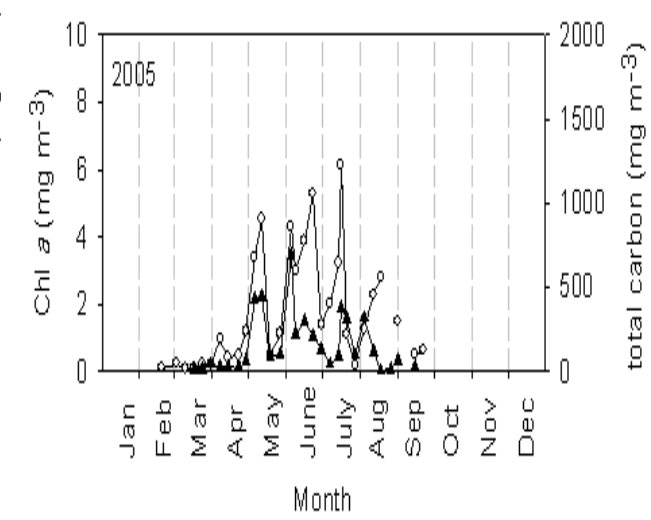

Figure (3): Distribution of HPLC estimated Chl $a$ at Calshot and NWN in relation to variations in total phytoplankton biomass during 2004 and 2005 
2004
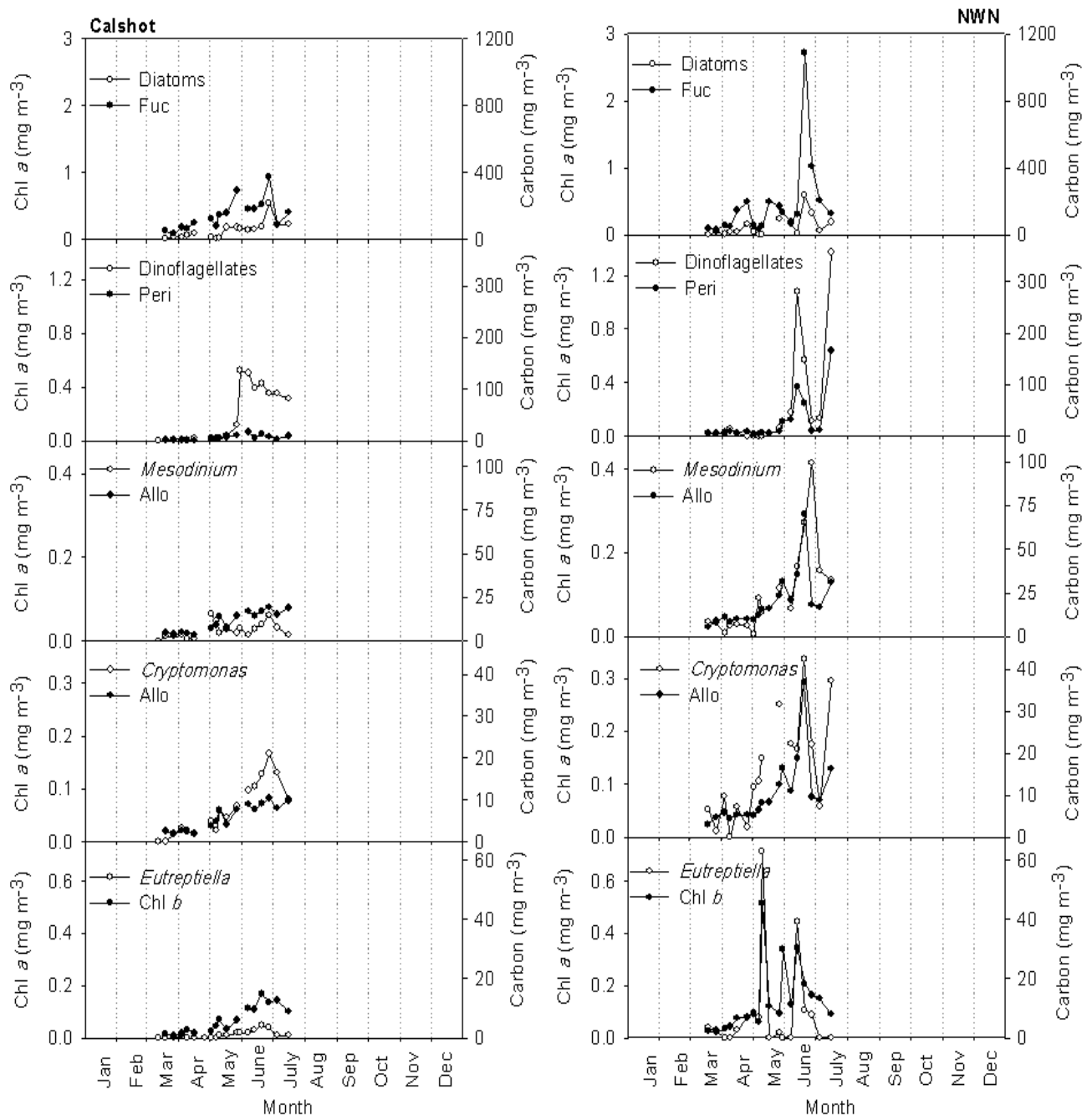

Figure (4): Distribution of 4 specific biomarker pigments (fucoxanthin (Fuc), Peridinin (Peri), alloxanthin (Allo) and, Chl b) at Calshot and NWN in relation to variations in carbon biomass of the relevant group and/or species identified during 2004

\section{Phytoplankton biomarker pigments and Community composition}

About 20 pigments were recorded from the HPLC absorbance chromatogram, among which (in addition to Chlorophyll $a$ as an indicator of the total phytoplankton biomass) 7 important pigments $\left(>0.1 \mathrm{mg} \mathrm{m}^{-3}\right)$ were selected as primary taxonomic markers of the dominant phytoplankton groups; fucoxanthin (Fuc) for diatoms together with Diadinoxanthin (Diad) and 
chlorophyll $c_{1}+c_{2}\left(\mathrm{Chl} c_{1}+c_{2}\right.$ ), Peridinin (Peri) for dinoflagellates, alloxanthin (Allo) for cryptophytes, chlorophyll $b(\mathrm{Chl} b)$ for chlorophytes and chlorophyll $c_{3}$ $\left(\mathrm{Chl} c_{3}\right)$ for prymnesiophytes. Some other pigments (e.g. 19' hexanoyloxyfucoxanthin, 19'butanoyloxyfucoxanthin, violaxanthin, zeaxanthin and prasinoxanthin) were recorded in small traces $\left(\sim<0.1 \mathrm{mg} \mathrm{m}^{-3}\right)$ in some samples of which, 19' hexanoyloxyfucoxanthin $\left(19^{`} \mathrm{Hex}\right)$ was included in the next analysis as an important pigment for prymnesiophyta. Ranges of the selected pigment concentrations are given in Table (2) .The breakdown products (phaeophorbides $a 1$ and $a 2$ and phaeophytin $a 1$ and $a 2$ ) are not included in the following data analysis as the indications beyond these products are not of this work interest; however, they were detected in the HPLC chromatogram.

Table (2): Range of concentrations (minimum and maximum) of the specific pigments $\left(\mathrm{mg} \mathrm{m}^{3}\right)$ detected from Southampton water estuary in 2004 and 2005. Values in brackets are for Calshot (CA).

\begin{tabular}{|l|c|c|c|c|}
\hline \multirow{2}{*}{} & \multicolumn{2}{|c|}{ 2004 } & \multicolumn{2}{c|}{2005} \\
\cline { 2 - 5 } & Minimum & Maximum & Minimum & Maximum \\
\hline Chl $\boldsymbol{a}$ & $0.19 \pm \mathbf{0 . 1 9}$ & $2.12 \pm \mathbf{6 . 1 0}$ & $0.04 \pm \mathbf{0 . 0 7}$ & $6.65 \pm \mathbf{0 . 1 4}$ \\
\hline Chl $\boldsymbol{c}_{\boldsymbol{l}}+\boldsymbol{c}_{2}$ & - & $0.18 \pm \mathbf{0 . 4 5}$ & - & $0.20 \pm \mathbf{0 . 3 9}$ \\
\hline Chl $\boldsymbol{c}_{3}$ & - & $0.11 \pm \mathbf{0 . 1 5}$ & - & $0.80 \pm \mathbf{3 . 1 0}$ \\
\hline Chl b & $0.01 \pm \mathbf{0 . 0 2}$ & $0.17 \pm \mathbf{0 . 4 1}$ & - & $0.48 \pm \mathbf{0 . 5 4}$ \\
\hline Fuc & $0.09 \pm \mathbf{0 . 0 8}$ & $0.94 \pm \mathbf{2 . 7 2}$ & $0.06 \pm \mathbf{0 . 0 3}$ & $3.43 \pm \mathbf{3 . 7 6}$ \\
\hline Peri & - & $0.06 \pm \mathbf{0 . 0 6}$ & - & $0.13 \pm \mathbf{1 . 1 8}$ \\
\hline 19 Hex & $0.01 \pm \mathbf{0 . 0 1}$ & $0.08 \pm \mathbf{0 . 0 8}$ & - & $0.55 \pm \mathbf{0 . 3 1}$ \\
\hline 19 But & - & $0.02 \pm \mathbf{0 . 0 3}$ & - & $0.14 \pm \mathbf{0 . 1 1}$ \\
\hline Allo & $0.02 \pm \mathbf{0 . 0 2}$ & $0.08 \pm \mathbf{0 . 2 9}$ & - & $0.36 \pm \mathbf{0 . 2 6}$ \\
\hline Zea & - & $0.01 \pm \mathbf{0 . 0 3}$ & - & $0.45 \pm \mathbf{0 . 2 2}$ \\
\hline Diad & $0.01 \pm \mathbf{0 . 0 1}$ & $0.09 \pm \mathbf{0 . 4 2}$ & - & $0.33 \pm \mathbf{0 . 4 8}$ \\
\hline
\end{tabular}

N.B. Chl $a$ (chlorophyll $a$ ), Chl $c_{1}+c_{2}$ (chlorophyll $c_{1}+c_{2}$ ), Chl $c_{3}$ (chlorophyll $c_{3}$ ), Chl $b$ (chlorophyll $b$ ), Fuc (fucoxanthin), 19 Hex (19'-hexanoyloxyfucoxanthin), 19 But (19'-Butanoyloxyfucoxanthin,), Allo (alloxanthin), Diad (diadinoxanthin), Zea (zeathanthin), - Undetected or zero.

The pattern of change in total phytoplankton biomass (expressed as total carbon) was similar to that of HPLC measured chlorophyll $a$ (see Figure 3), although some variations were detected on some dates (e.g. at NWN in 2005). For example, two major peaks $\left(>10 \mathrm{mg} \mathrm{m}^{-3}<20 \mathrm{mg} \mathrm{m}^{-3}\right.$ ) of chlorophyll $a$ was measured in July and a smaller peak $\left(<10 \mathrm{mg} \mathrm{m}^{-3}\right)$ in August at NWN, however, no peaks in carbon biomass were microscopically detected at the same time.

Microscopic analysis of water samples during sampling years revealed that phytoplankton community composition was mainly dominated by diatoms and dinoflagellates, while smaller-sized species (e.g. flagellates) were numerically 
abundant in some water samples. HPLC data showed that over the sampling period fucoxanthin (see Figures 4 and 5) and chlorophyll $c_{1}+c_{2}$ (not shown) were the most abundant taxonomic pigment in spring/early summer at both sites, indicating that diatoms dominated the phytoplankton assemblages at this time of the year.

2004
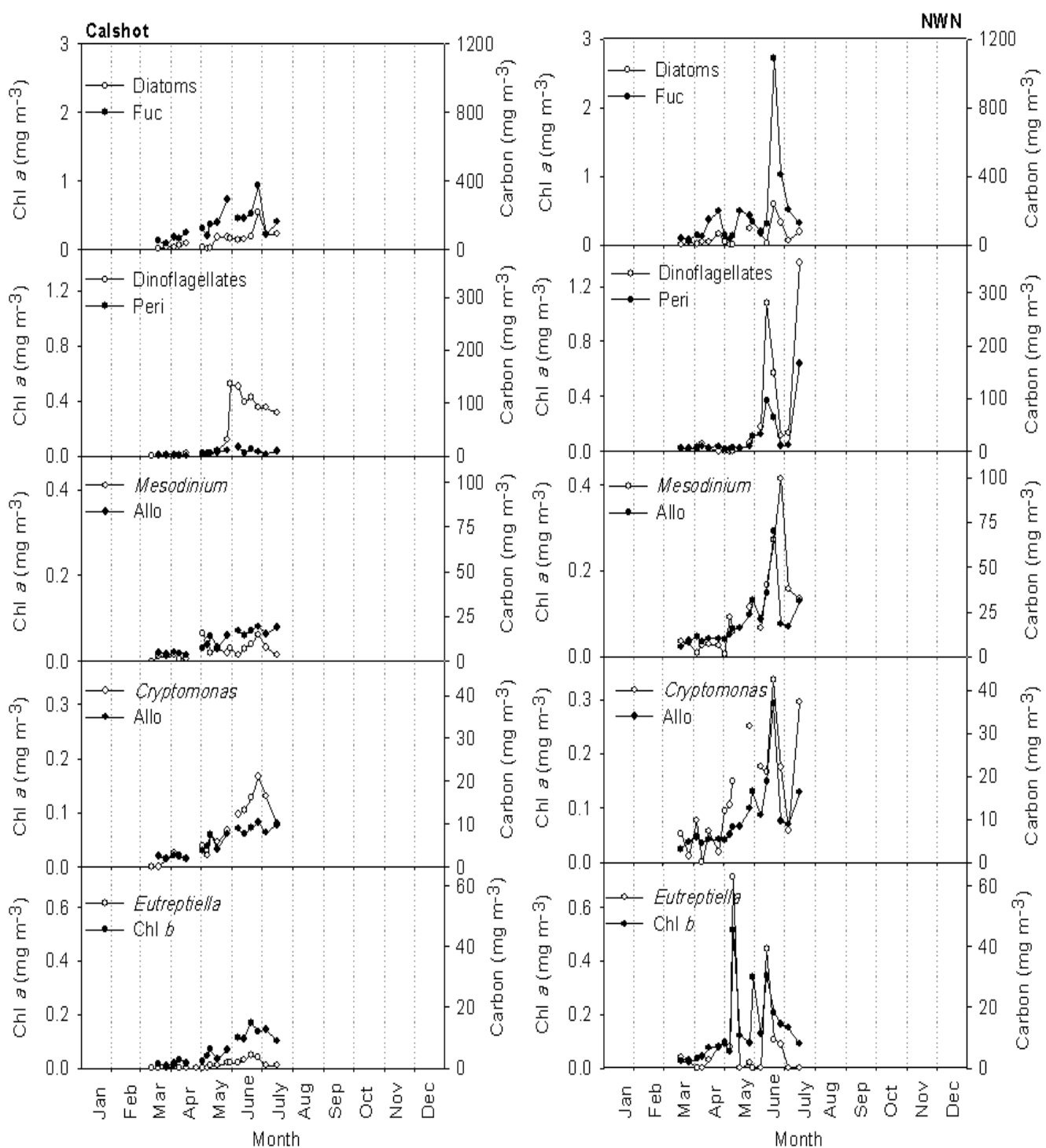

Figure (4): Distribution of 4 specific biomarker pigments (fucoxanthin (Fuc), Peridinin (Peri), alloxanthin (Allo) and $\mathrm{Chl} b$ ) at Calshot and NWN in relation to variations in carbon biomass of the relevant group and/or species identified during 2004 

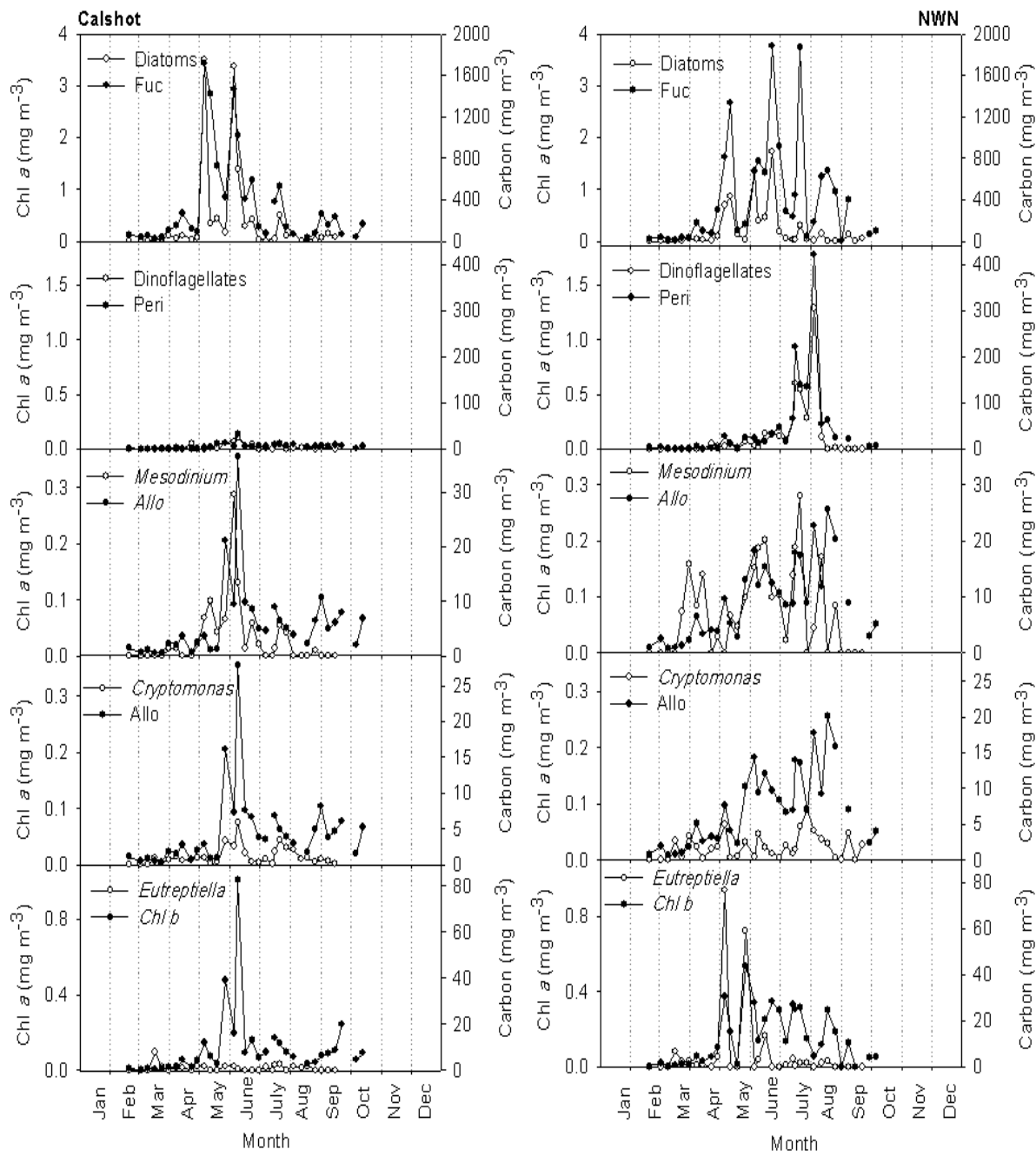

Figure (5): Distribution of 4 specific biomarker pigments (fucoxanthin (Fuc), Peridinin (Peri), alloxanthin (Allo) and, $\mathrm{Chl} b$ ) at Calshot and NWN in relation to variations in carbon biomass of the relevant group and/or species identified during 2005

Fucoxanthin generally showed temporal variations during the sampling period with highest peaks recorded during May at the time of the diatom bloom of Guinardia delicatula, whereas, in 2004 the biomass peak delayed until end of June at both sites when a diatom mixture of the genera Guinardia delicatula and Cerataulina pelagica were dominant. Other relatively high peaks of fucoxanthin 
were measured late in July at NWN in all years. These peaks mostly coincided with the bloom of Chaetoceros spp. and small pennate diatoms (e.g. Nitzschia closterium, Nitzschia serriata). Although, high fucoxanthin peaks were recorded at NWN (Figure 5) in 2005 (July and August), these peaks could not be identified microscopically, this could be due to the dominance of smaller pinnate diatoms $(<2 \mu \mathrm{m})$ that difficult to recognised by light microscopy. A strong correlation $(\mathrm{p}$ $<0.001$ ) between fucoxanthin concentrations and chlorophyll $a$ was recorded in both years with $r$ values ranged between $0.88-0.96$, for both years, indicating the dominance of diatoms in Southampton Water estuary. Highest concentrations (maximum $0.45 \mathrm{mg} \mathrm{m}^{-3}$ in 2004 and $0.39 \mathrm{mg} \mathrm{m}^{-3}$ in 2005) of chlorophyll $c_{1}+c_{2}$ (included in most diatoms) were measured during spring bloom (May/June) of the diatom Guinardia delicatula (at Calshot) and Thalassiosira and Nitzschia (at NWN). A good correlation of Chl $c_{1}+c_{2}$ however less than that of fucoxanthin, to chlorophyll $a$ was found $(\mathrm{r}=0.73)$ with a more scattered plot between both variables especially when large-celled chlorophyll-rich diatoms (e.g. Guinardia delicatula and Rhizosolenia setigera) were mostly abundant. Variations in cell pigment/chlorophyll $a$ ratio among species could be an explanation of the discrepancy of the scatter plot.

Diadinoxanthin, which is a dark-induced pigment included in most diatoms, was found with variable concentrations ranging between $0.01-0.48 \mathrm{mg}$ $\mathrm{m}^{-3}$ (Table 2) during both sampling years with highest values of 0.42 and $0.48 \mathrm{mg}$ $\mathrm{m}^{-3}$ at NWN in 2004 and 2005, respectively. The temporal and spatial variations in diadinoxanthin concentration (data not represented) and correlation with Chlorophyll $a$ were similar to that of fucoxanthin, however, a scattered correlation was found between diadinoxanthin and chlorophyll $a$ in some occasions for the reason mentioned above.

Low concentrations of peridinin, the major carotenoid for autotrophic Dinophyceae, were mostly measured in spring at both sites during the sampling period (see Figures 4 and 5) but increased towards the end of the sampling period with highest concentrations in summer (July/August). Maximum concentration in Peri of $1.78 \mathrm{mg} \mathrm{m}^{-3}$ was detected at NWN in 2005. This was during the summer dinoflagellate bloom, which was mainly composed of Scrippsiella trochoidea with Prorocentrum micans and Gymnodinium sp. in some samples. Insignificant correlations between peridinin and chlorophyll $a(\mathrm{r}=0.3)$ was generally recorded over the sampling period, indicating that dinoflagellates, with the exception of August bloom, contributed less to the total phytoplankton biomass along the estuary over the sampling period. This could be also related to the exclusive abundance of the relatively large-sized diatoms (e.g. the dominance of Guinardia delicatula and Rhizosolenia spp. during spring/summer in both years). Dinoflagellates were, however much contributed to the total phytoplankton biomass 2004 compared to 2005. It is worth mentioning that peridinin 
concentration was much higher at NWN (the middle part of the estuary) compared to that in coastal waters. This indicated that diatom species replaced dinoflagellates with increasing water turbulence. Dinoflagellates are known to live preferably at NWN where high daily irradiance and calm water state compared (Ali et al., 2000 and Ali, 2009).

Alloxanthin (Allo), the major biomarker of Cryptophyceae was detected with different concentrations during sampling period with a range of $0.01-0.29$ $\mathrm{mg} \mathrm{m}^{-3}$ in 2004 and $0.01-0.33 \mathrm{mg} \mathrm{m}^{-3}$ in 2005 (Table 2). Although variations in alloxanthin and biomass of the cryptophycean species, Cryptomonas showed no similarities in most dates (see Figures 4 and 5), smaller peaks of alloxanthin were coincided with peaks of the biomass of Cryptomonas during 2004 (Figure 4) and 2005 (Figure 5) when this species was numerically abundant and achieving high population (> $250 \mathrm{cell} / \mathrm{ml})$. Modest to strong correlations $(\mathrm{r}=0.6-0.76)$ were found between the pigment and chlorophyll $a$ in all years particularly at NWN indicating that smaller flagellates $(<5 \mu \mathrm{m})$ were significantly contributed to phytoplankton population at this site and was difficult to recognize by light microscopy. Some peaks of alloxanthin were coincided with peaks of the biomass of ciliate Mesodinium rubrum in 2004 (Figure 4) and 2005 (Figure 5), particularly at NWN when this species was achieving higher population. Concentrations of chlorophyll $b$, the carotenoids pigment of green algae widely varied over the sampling period (Figures 4 and 5) but occurred in lower concentrations (0.00-0.54

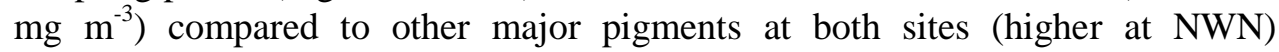
indicating that green algae (i.e. Chlorophyta) were relatively less contributing to the total phytoplankton community in Southampton Water (compared with Bacillariophyceae and Dinophyceae). Highest levels in $\mathrm{Chl} b$ was recorded during year $2005\left(0.48\right.$ and $\left.0.54 \mathrm{mg} \mathrm{m}^{-3}\right)$, particularly at NWN. Despite the fact that peaks in the biomass of the flagellate Eutreptiella marina in 2004 and 2005 (during May - June) coincided with peaks in Chl $b$ (Figures 4 and 5) and the fact that $\mathrm{Chl} b$ correlated significantly to chlorophyll $a$ in both years ( $\mathrm{r}=0.77$ in 2004 and $r=0.79$, in 2005), poor correlation ( $r<0.3)$ was found between carotenoids and the biomass of Eutreptiella marina. This finding might indicate that this flagellate is not the only chlorophyceans in Southampton Water.

Chlorophyll $c_{3}$ (Chl. $\left.c_{3}\right)$ was mostly found in low concentration $(0.0-$ $0.15 \mathrm{mg} \mathrm{m}^{-3}$ ) at both sites apart from three high peaks recorded in 2005 particularly at NWN during summer (see Figure 6). These peaks of chlorophyll $c_{3}$ might indicated the presence of Prymnesiophytes or/and Chrysophytes (both include Chlorophyll $\left.c_{3}\right)$, of which most species are small in size $(<2 \mu \mathrm{m})$ and are difficult to recognize microscopically. This finding might explain the last 3 unidentified fucoxanthin peaks (Figure 5) during July and August at this site (both Prymnesiophytes and Chrysophytes include fucoxanthin as well as Chl $c_{3}$ ). Lowest concentrations in $\mathrm{Chl} c_{3}$ were generally measured in year 2004 (Figure 6). 

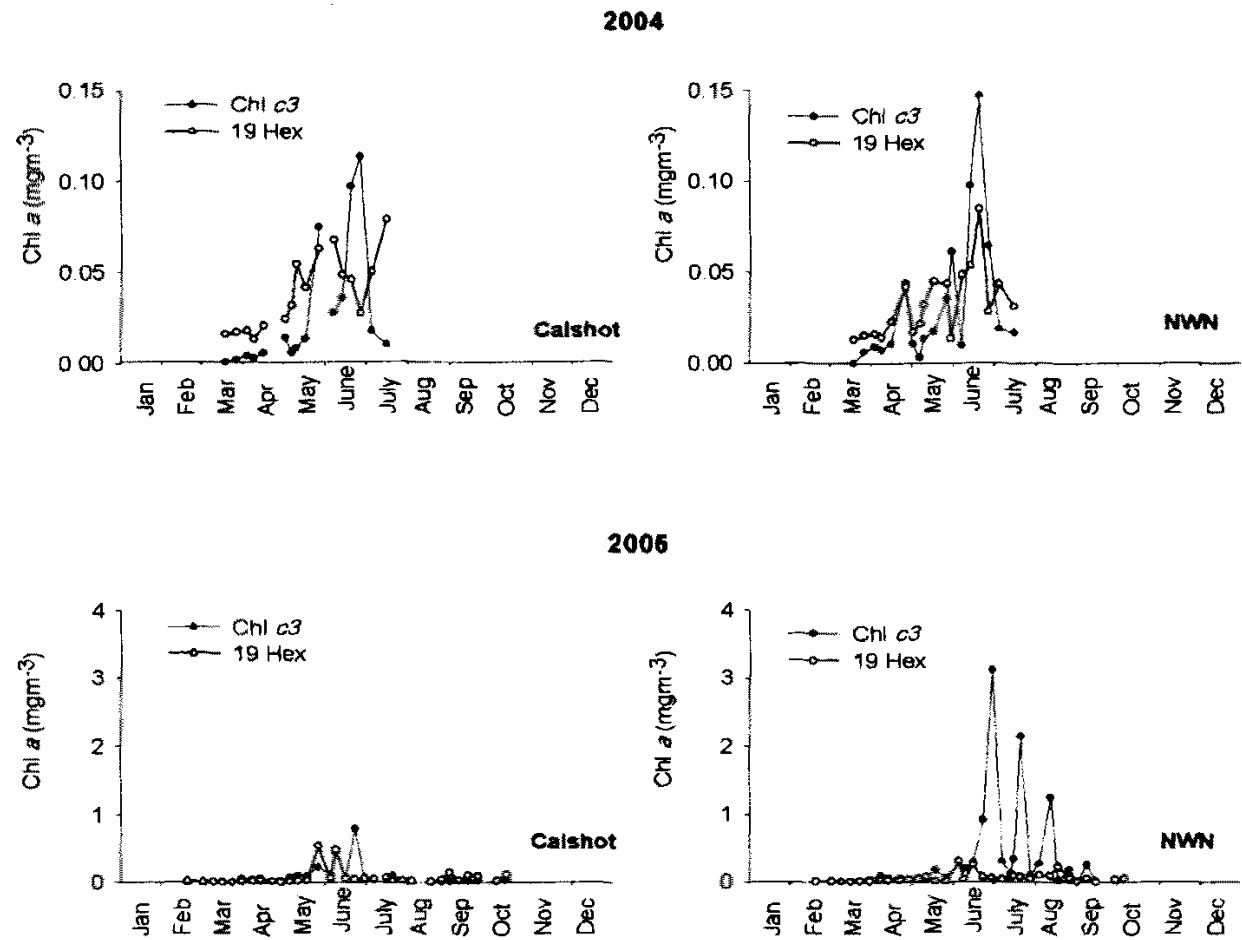

2006

Figure (6): Variations in Chl $c_{3}$ and 19 Hex at Calshot and NWN during 2004 and 2005

Microscopic analysis of phytoplankton confirmed that no prymnesiophycean species were noticed at this year. In contrast, Phaeocystis was numerically dominated the mid May phytoplankton community at Calshot; however no noticeable peak in chlorophyll $c_{3}$ was measured at this time.

\section{Discussion}

\section{Pigment concentrations and internal relationship}

Total chlorophyll $a$ concentration from HPLC and acetone extraction (fluorometric chlorophyll $a$ ) showed a good significance $(\mathrm{r}=0.94, p<0.001$ ) between both methods (Figure 7a) with relatively similar variation patterns (Figure 2 and 3) although the later was always overestimated by a mean value of $0.2 \%$ - 38\%. This could be due to the interference of other pigment and chlorophylls according to the method used (Barlow, pers. Comm.)

Figure 7b showed that HPLC measurements of Chlorophyll $a$ significantly $(p>0.001)$ correlated with that of total accessory pigments (carotenoids, Chlorophyll $c$ and Chlorophyll $b$ ) with a mean correlation 
coefficient $(r=0.91)$ close to the value $(r=0.89)$ previously suggested by Trees et al. (2000). Such relationship indicates that chlorophyll $a$ can be used as internal comparison of HPLC measurements of other pigments This also indicates that chlorophyll $a$ concentrations are related to the concentration of accessory pigments despite variations in cell physiology and community structure which, might led to a more scattered relationship between both variables (lower correlation coefficient) and increase the discrepancy of the scatter plot.
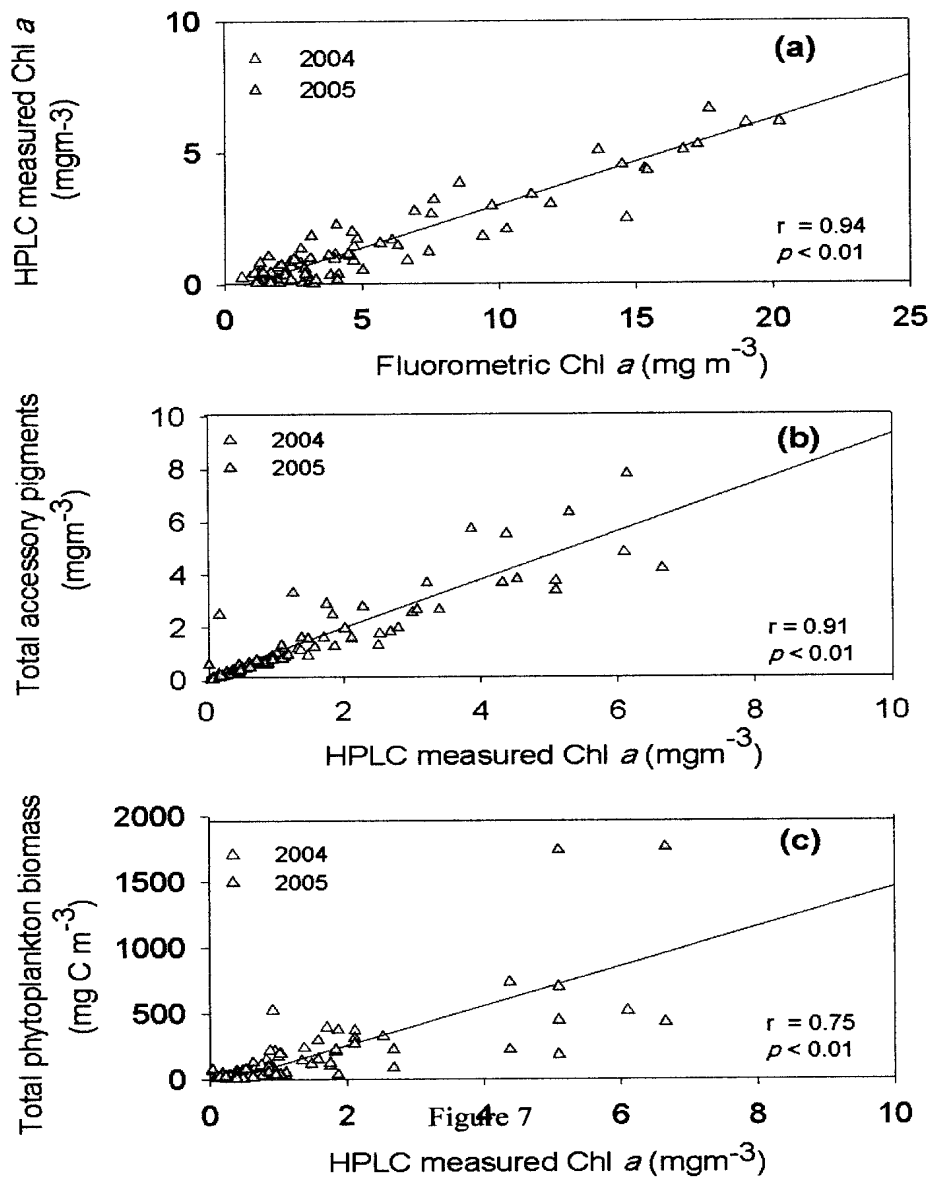

Figure (7): Plot and regression results ( $r$ value and significance level, $p$ ) of a)fluorometric $\mathrm{Chl} a$ concentration versus the HPLC measured $\mathrm{Chl} a$, b) HPLC measured Chl $a$ versus total accessory pigments.

\section{c) HPLC measured Chl $a$ versus total phytoplankton biomass}

**All measurements during 2004 and 2005 of both sites were grouped for the regression line. 
HPLC measured chlorophyll $a$ showed a very similar spatial and temporal variation to that of the total phytoplankton biomass over the sampling period (Figure 3), with a significant correlation $(r=0.75$, Figure $7 \mathrm{c})$.

HPLC measured chlorophyll $a$ was, however, not always give a good estimation (Breton et al., 2000) of the total phytoplankton biomass. In this work, some variability between both variables was, however, detected at some dates (e.g. at NWN in 2004 (July) and in 2005 (August)) this could be related to the differences in carbon/chlorophyll ratio among phytoplankton species. This might occurred when species with high chlorophyll content species are over dominated. Difficulty to distinguish heterotrophic phytoplankton species during identification and counting might lead to incorrect biomass evaluations causing. Breton et al., (2000) recommended using chlorophyll $a$ as a biomass indicator should be undertaken with caution according to the environmental conditions (e.g. nitrogen depletion, light stress and seasonal variations). Highest concentrations of both variables was detected during June 2004 at both sites (maximum at NWN) during the diatom bloom (mainly Guinardia sp.), however, in 2005, more than one peak of both phytoplankton biomass indicators (Chl $a$ and carbon) were detected during the period from May to early August. Phytoplankton community structure widely changed during that time at both sites from a diatom-dominating community in May/June; Guinardia delicatula during May and Thalassiosira rotula during June. Both diatom species are common in Southampton Water and known to achieve high abundance (e.g. Kifle and Purdie, 1993). Dinoflagellate species (mainly, Scrippsiella trochoidea) was then replaced diatoms (during July) until diatoms flourished again at the end of July/August with a different species composition (Chaetoceros spp. and Cosinodiscus were dominated). Flagellates (e.g. Cryptomonas) were numerically over dominating in June, when and after Thalassiosira sp was abundant. A similar succession of phytoplankton species was previously reported for Southampton Water (e.g. kifle and Purdie, 1993; Crawford and Purdie, 1993; Ali, 2003 and 2009).

Good agreement was found between the concentration of the biomarker pigments and the biomass of their respective class and/or species at both sites (Figure 4 and 5). Diatoms $(r=0.72)$ and dinoflagellates $(r=0.74)$ showed the best correlation with their respective pigment marker fucoxanthin and peridinin (Jeffrey and Wright, 1994; Delizo et al., 2007), respectively (Table 3). It was clearly identified, from the HPLC pigment analysis that dinoflagellates tend to grow favourably during summer, with increasing irradiance level and reducing rainfall and the flow rate. It was also noticeable that they grow better in intermediate sites in relatively calm water environment than in highly turbulent waters (coastal waters). Although, higher diatom biomass recorded in mid estuary, they grow also well in coastal waters, however, the diatom community composition may vary. Microscopic analysis of phytoplankton showed that the 
growth peak of the diatom Guinardia delicatula occurred in May/early June at both sites with a maximum level at coastal waters. This diatom was previously reported to in Southampton Water forming blooms during May (e.g. Kifle and Purdie, 1993).

Table (3): Results of the linear regression analysis of some HPLC derived data versus other relevant data. Table includes the Pearson's moment correlation coefficients $r$, significance level s and confidence percentage (\%).

\begin{tabular}{|c|c|c|c|}
\hline & $\begin{array}{c}\mathbf{R} \\
\text { value } \\
(\mathbf{r})\end{array}$ & $\begin{array}{c}\text { Significance } \\
\text { level (s) }\end{array}$ & $\begin{array}{c}\% \\
\text { Confidence }\end{array}$ \\
\hline HPLC measured Chl $a V s$. Fluorometeric Chl $a$ & 0.94 & $<0.001$ & $\mathbf{9 8 \%}$ \\
\hline HPLC measured Chl $a$ Vs. T. accessory pigments & 0.91 & $<0.001$ & 98\% \\
\hline HPLC measured Chl $a$ Vs. T. phytoplankton biomass & 0.75 & $<0.001$ & $\mathbf{9 8 \%}$ \\
\hline Fuc Vs. Total diatom biomass & 0.72 & $<0.001$ & $\mathbf{9 8 \%}$ \\
\hline Peri Vs.Total dinoflagellates biomass & 0.74 & $<0.001$ & $95 \%$ \\
\hline Allo Vs. biomass of Cryptophyceans & $\mathbf{0 . 3 3}$ & $<0.005$ & $95 \%$ \\
\hline $\begin{array}{l}\text { Chl } b \text { Vs. Total biomass of green algae (Only } \\
\text { Eutreptiella in this research }\end{array}$ & 0.44 & $<0.005$ & $95 \%$ \\
\hline Chl $c_{3} V s .19$ 'Hex & 0.27 & $<0.05$ & $>95 \%$ \\
\hline
\end{tabular}

Alloxanthin is the pigment biomarker for Cryptophycea (Jeffrey et al., 1999). The quality of the relationship between both variables is well documented by Jeffrey and Vesk, (1997). Alloxanthin is however showed no correspondence ( $\mathrm{r}=0.33$, Table 3 ) with Cryptophyceae (only Cryptomonas sp in this work). This was due to the confusion occurred during microscopic count when other small flagellates $(2 \mu \mathrm{m})$ were numerically very abundant $\left(>1400\right.$ cells ml $\left.^{-1}\right)$. Peaks in alloxanthin were, however, coincided with peaks of the autotrophic ciliate, $M$. rubrum on some dates. This seemed to be due to endosymbiont (Jeffrey and Vesk, 1997) as described by Gieskes and Kraay (1983). Alloxanthin, is detected in the ciliate Mesodinium rubrum (Hibberd, 1977), which could contain cryptophytes as endosymbionts as described by Gieskes and Kraay (1983). Presence of some specific pigments in several species and/or groups could give false or inaccurate indications (Breton et al., 2000; Rodriguez et al., 2002), which is one of the limitation in the chemotaxonomic methodology.

A modest to poor correspondence $(\mathrm{r}=0.44)$ was estimated between chlorophyll $b$ and the total biomass of green algae (mainly Eutreptiella marina) in most samples analysed from Southampton water. The reason for not obtaining a stronger relationship (Table 3 ) between both variables could be explained by the small cells of green algae that could be missed in microscopic counting. A study 
conducted in the eastern English Channel (Breton et al., 2000) supported this finding. The fact that small flagellates may not survive sample fixation (Reid, 1983 and Booth et al., 1993) could be another explanation for the poor relationship between both variables.

To conclude, the comparison of the microscopic and HPLC pigment techniques allowed us to evaluate several methodological issues for monitoring phytoplankton distribution and species diversity. The high agreement between microscopy and chemotaxonomy found in this study suggests that both methodologies can be used efficiently for the characterization of phytoplankton community of estuaries and coastal waters. Both techniques revealed changes in phytoplankton species composition and biomass along the estuary and succeeded to identify and quantify the dominant group of different phytoplankton assemblages and in such highly variable system, but so me limitations are present in both techniques.

The use of specific biomarker pigments analysed by HPLC method of water samples collected from Southampton Water provided considerable insight into the seasonal variability of phytoplankton community composition and species succession throughout the estuary. Microscopic observations is, however, still needed to identify the taxa contributing to these specific accessory pigments as recommended also by Breton et al. (2000) (2001) and Ansotegui et al.. It is also recommended the use of scanning electron microscopy and epifluorescence microscopy for small cells. Finally, a further research is needed to assess the correct application of the chemotaxonomy to ecological studies of natural phytoplankton assemblages.

\section{References}

Ali, E. M. (2009). "Phytoplankton blooms in macrotidal estuaries':VDM, Verlag,, Schaltungdienst Lange O. H. G. Berlin, 238 Dr. Muller, Schaltungdienst Lange O. H. G. Berlin, 238.

Ali, E. M. (2003). Processes and conditions influencing phytoplankton growth and bloom initiation". Ph D. thesis, NOC, University of Southampton, UK.

Ali, E. M.; Purdie, D. A. and Holley, S. E. (2000). Investigations of optimal conditions for phytoplankton growth in a macrotidal estuary: Application of continuous monitoring and discrete water sampling methods, Proceedings (Vol. 1) of the UK Marine science, University of East Anglia, Norwich, UK.

Ansotegui, A., Trigueros, J. M., Orive, E. (2001). The use of pigment signatures to assess phytoplankton assemblage structure in estuarine waters. Estuarine, Coastal and Shelf Sci., 52: 689-703. 
Barlow, R.G.; Mantoura, R.F.C.; Gough, M. A. and Fileman, T.A. (1993). Pigment signatures of the phytoplankton composition in the northeastern Atlantic during the 1990 spring bloom. Deep-Sea Res., II 40: 459-477.

Booth, B.C.; Lewin, J. and Postel, J.R. (1993). Temporal variation in the structure of autotrophic and hetrotrophic communities in the subarctic Pacific. Progress in Oceanography, 32:57-99.

Breton, E.; Brunet, C.; Sautour, B. and Brylinski, J. M. (2000). Annual variations of phytoplankton biomass in the eastern English Channel: comparison by pigment signatures and microscopic counts. J. Plank. Res., 22: 1423-1440.

Claustre, H.; Hooker, B.S.; Van Heukelem, L.; Berthon, J.F.; Barlow, R.; Ras, J.; Sessions, H.; Targa, C.; Thomas, C.S.; van der Linde, D. and Marty, J.C. (2004). An inter comparison of HPLC phytoplankton pigment methods using in situ samples: application to remote sensing and database activities. Marine Chemistry, 85: 41-61.

Cloern, J. E. (1996). Phytoplankton blooms dynamics in coastal ecosystem: A review with some some general lessons from a sustained investigation of San Francisco Bab, California. Reviews of Geophysics, 34: 127-168.

Crawford, D. and Purdie, D. A. (1993). Evidence for avoidence of flushing from an estuary by planktonic phototrophic ciliate. Mar. Ecol. Prog. Ser.,79: 259-265.

Delizo, L.; Smith, W. O. and Hall, J. (2007). Taxonomic composition and growth rates of phytoplankton assemblages at the Subtropical Convergence east of New Zealand. Journal of Plankton Research, 29:655-670.

DiTullio, G.R.; Geesey, M.E.; Jones, D.R.; Daly, K.L.; Campbell, L. and Smith Jr., W.O. (2003). Phytoplankton assemblage structure and primary productivity along $170^{\circ} \mathrm{W}$ in the South Pacific Ocean. Mar. Eco. Prog. Series, 255:55-80.

Ediger, D.; Soydemir, N. and Kideys, A.E. (2006). Estimation of phytoplankton biomass using HPLC pigment analysis in the southwestern Black Sea. Deep Sea Res. Part II: Topical Studies in Oceanography,53:1911-1922.

Eppley, R. W.; Reid, F.M.H. and Strickland, J.D.H (1970). Ecology of the plankton of La Jolla, California, in the period April through September 1967. Bull. Scripps. Inst. Oceanogr., 17: 33-42.

Fujiki, T.; Matsumoto, K.; Honda, M. C.; Kawakami, H. and Watanabe, S. (2009). Phytoplankton composition in the sub arctic North Pacific during autumn 2005. Journal of Plankton Research, 31:179-191.

Gieskes, W. W. C. and Kraay, G. W. (1983). Dominance of Cryptophyceae during the phytoplankton spring bloom in the central North Sea detected by HPLC analysis of Pigments. Mar. Biol., 75: 179-185. 
Hibberd, D. J. (1977). Observations on the ultrastructure on the cryptomonad endosymbiont of the red-water ciliate Mesodinium rubrum. J. of the Mar. Biol. Ass. UK, 57: 45-61.

Holley, S. E.and Hydes, D. J. (2002). Ferry-Boxes and data stations for improved monitoring and resolution of eutrophication-related processes: application in Southampton Water UK, a temperate latitude hupernutrified estuary. Hydrobiologia, 475/476: 99-110.

Holligan, P. M.; Harris, R.P.; Newell, R.C.; Harbour, D.S.; Head, R.N.; Lidley, E.A.S.; Lucas, M.I.; Tranter, P.R.G and Weekly, C.M. (1984). Vertical distribution and partitioning of organic carbon in mixed, frontal and stratified waters of the English Channel. Mar. Ecol. Prog. Ser., 14: 111-127.

Iriarte, A. and Purdie, D.A. (2004). Factors controlling the timing of major spring bloom events in an UK south coast estuary. Estuarine, Coastal and Shelf Science, 61: 679-690.

Jeffrey, S. W. and Vesk, M. (1997). Introduction to marine phytoplankton and their pigment signature. in: Jeffrey, S. W., Mantoura, R.F.C., Wright, S.W. (Eds), Phytoplankton pigments in oceanography: Guidelines to modern methods. UNESCO, Paris. p 19-36.

Jeffery, S. W. and Wright, S. W. (1994). Photosynthetic pigments in the Haptophyta. In Green, J.C. and Leadbeater, D.S.C. (eds). Oxford, Clarendon Press.

Jeffrey, S. W.; Llewellyn, C. A.; Barlow, R.G. and Mantoura, R.F.C. (1997). Pigment processes in the sea: a selected bibliography. Phytoplankton Pigments in Oceanography: A Guide to Advanced Methods. S. W. Jeffery, Mantoura, R.F.C. and Wright, S.W. (eds). Paris, SCORUNESCO: 167-178.

Jeffrey, S. W.; Wright, S.W. and Zapata, M. (1999). Recent advances in HPLC analysis of phytoplankton. Mar. Res., 50: 879-896.

Kifle, D. P. and Purdie, D. A. (1993). The seasonal abundance of the phototrophic ciliate Mesodinium rubrum in Southampton Water, England. Journal of Plankton Research, 15: 823-833.

Kovala, P. E. and Larrance, J.D. (1966). Comparison of phytoplankton cell numbers, cell volume, cell surface and plasma volume, per metre, from microscopic counts. Univ. Washington Spec. Rep., 36: 1-21.

Llewellyn, C.A.; Fishwick, J.R. and Blackford, J.C. (2005). Phytoplankton community assemblages in the English Channel: a comparison using chlorophyll a derived from HPLC-CHEMTAX and carbon derived from microscopy cell counts. Journal of Plankton Research, 27: 103-119.

Llewellyn, C. A.; Tarran, G. A. ; Galliene, C. P.; Cummings, D. G.; De Menezes, A. and Rees, A. (2008). Microbial dynamics during the decline of a spring diatom bloom in the Northeast Atlantic. Journal of Plankton Research, 30:261-273. 
Mantoura, R. F. C. and Llewellyn, C.A. (1983). The rapid determination of algal chlorophyll orophyll-a and carotenoid pigments and their breakdown products in a natural water by reverse-phase high performance liquid chromatography. Anal. Chim. Acta., 151: 297-314.

Menden-Deuer, S. and Lessard, E.J. (2000). Carbon to volume relationships for dinoflagellats, diatoms and other protisit plankton. Limnol. Oceanogr., 45: 569-579.

Millie, D. F.; Paerl, H. W. and Hurley, P. (1993). Microalgal pigment assessments using high performance liquid chromatography: A synopsis of organismal and ecological applications. Can. J. Fish. Aquat. Sci., 50: 2513-2527.

Parsons, T. R.; Maita, Y. and Lalli, C.M. (1984). A Manual of Chemical and Biological Methods for Sea Water Analysis. Pergamon, Oxford, 173.

Phillips, A. J. (1980). Distribution of chemical species. The Solent Estuarine System. An assessment of present knowledge, the natural environmental. Research Council Publication, 22: 44-61.

Ras, J.; Claustre, H. and Uitz J. (2008). Spatial variability of phytoplankton pigment distributions in the Subtropical South Pacific Ocean: comparison between in situ and predicted data. Biogeosciences, 5: 353-369.

Reid, F.M.H. (1983). Biomass estimation of components of the marine nanoplankton and picoplankton by the Utermohl setting technique. $J$. Plankton Res., 5: 235-252.

Rodriguez, F.; Varela,M. and Zapata, M. (2002). Phytoplankton assemblages in the Gerlache and Bransfield Straits (Antarctic Peninsula) determined by light microscopy and CHEMTAX analysis of HPLC pigment data. Deep-Sea Research Part Ii-Topical Studies in Oceanography, 49: 723747.

Schluter, L.; Mohlenberg, F.; Havskum, H. and Larsen, S. (2000). The use of phytoplankton pigments for identifying and quantifying phytoplankton groups in coastal areas: Testing the influence of light and nutrients on pigment/Chlorophyll a ratios. Mar. Ecol. Prog. Ser., 192: 49-63.

Sylaios, G. and Boxall, S.R. (1998). Residual currents and flux estimates in a partially-mixed estuary. Estuarine, Coastal and Shelf Sci., 46: 671 - 682.

Tomas, C. R. (1997). Identifying Marine Phytoplankton. California, USA, Academic press.

Trees, C. C.; Clark, D. K.; Bidigare, R.R.; Ondrusek M. E. and Mueller J. L. (2000). Accessory pigments versus chlorophyll a concentrations within the euphotic zone: A ubiquitous relationship. Limnol. Oceanogr., 45: 1130-1143.

Wong, C. S. and Crawford, D.W. (2006). Evaluation of phytoplankton pigments in an in-situ iron enrichment experiment in the subarctic NE Pacific, Deep-Sea Research II, 10:1016. 


\title{
التغيرات السنوية في مجتمع الهائمات النباتية في مصب ساوث هامبتون (الساحل

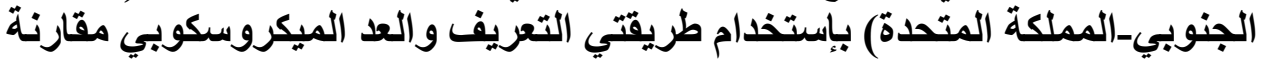 HPLC بالتصنيف الصبغي-الكيميائي لئئي
}

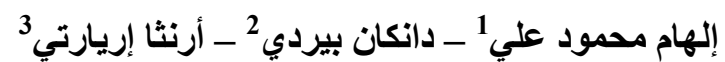

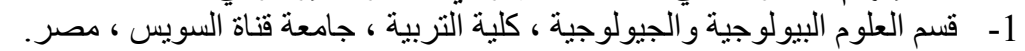

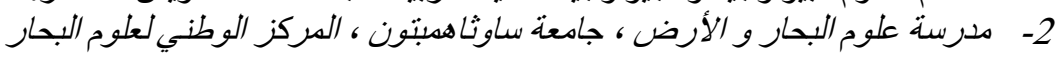

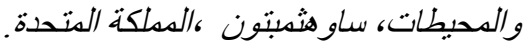 \\ 3- قسم علوم البيولوجية النباتية والبيئة ، جامعة الباسك ـ بيلباو ، إسبانيا
}

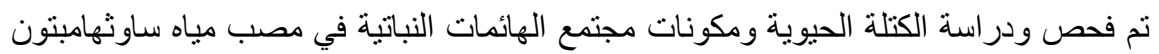

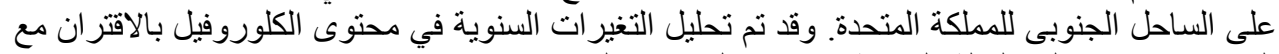

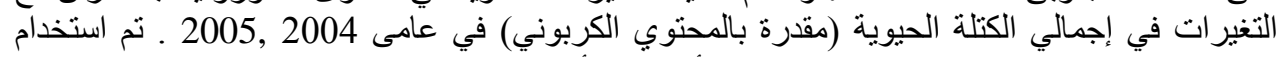

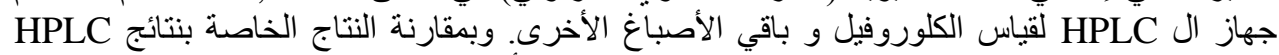

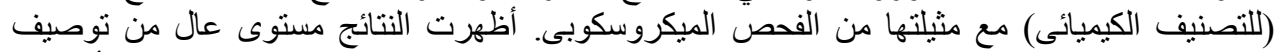

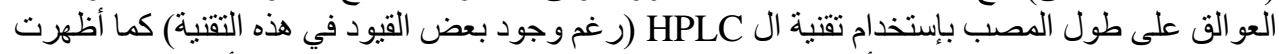

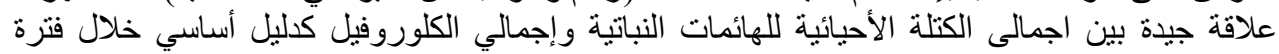
الدر اسة بالرغم من قلتها في بعض العضا العينات.

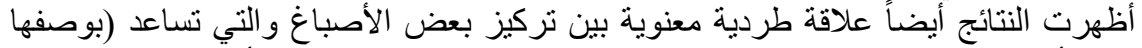

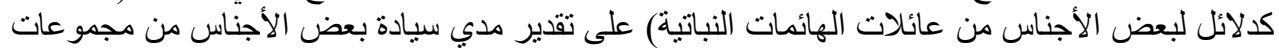

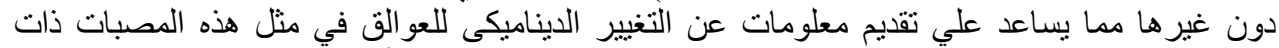

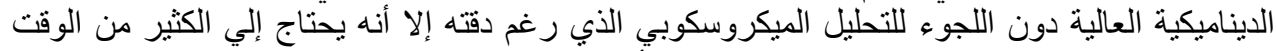

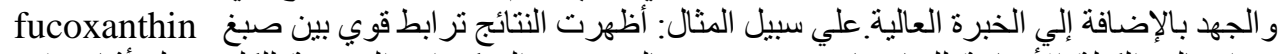

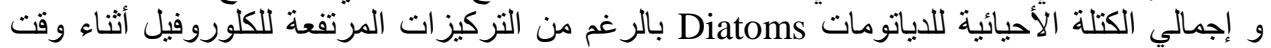

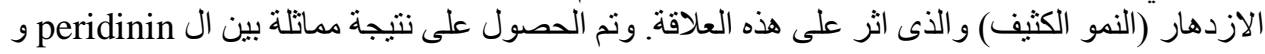

وبالنسبة لجنس Cryptomonas فبالرغم من أنه تم تسجيله في بعض عينات إلا أن العلاقة بين .Dinoflagellates.

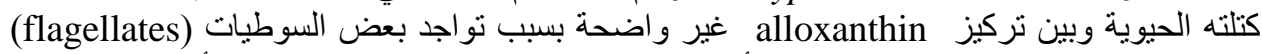

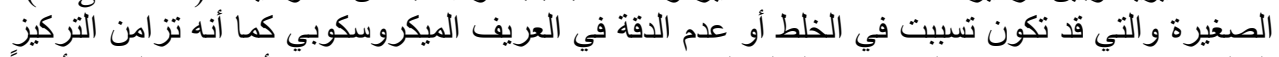

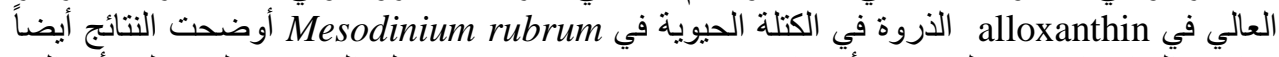

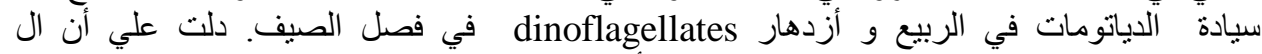
dinoflagellates وكذللك ال ciliates تتمو بشكل أفضل في المو اقع الوسيطة على طول المصب.
\end{abstract}

